\section{@Eleições2012: o processo \\ eleitoral em Curitiba e sua \\ relação com a mídia social}

@Elections2012: electoral process in

Curitiba and its relation with social media

Elza Aparecida de Oliveira Filha ${ }^{[a],}$

Thomas Mayer Rieger ${ }^{[b]}$ [a] Jornalista, doutora em Ciências da Comunicação pela Universidade do Vale do Rio dos Sinos (Unisinos), professora do curso de Jornalismo da Universidade Positivo (UP), Curitiba, PR- Brasil, e-mail: elzaap@hotmail.com

[b] Jornalista formado pela Universidade Positivo (UP), Curitiba, PR- Brasil, e-mail: thomasmr@hotmail.com

\title{
Resumo
}

O presente trabalho se insere num universo midiático relativamente novo, o das ferramentas de mídia social - notadamente Twitter, Facebook e YouTube, objetos desta pesquisa. Foi analisado, aqui, o desempenho dos candidatos à prefeitura de Curitiba nas eleições de 2012. Os dados foram coletados durante todo o período eleitoral, entre os meses de julho e outubro. A presença dos sete candidatos nas mídias sociais foi semanalmente verificada, com acompanhamento do incremento de postagens e do crescimento de seguidores - ou o processo inverso, conforme o caso. Foi feita também

Palavras-chave: Mídia social. Política. Eleições. 
uma comparação entre os dados alcançados neste trabalho e os números das pesquisas de intenção de voto, de institutos como Ibope e Datafolha. O objetivo principal foi comprovar que, em decorrência da existência de uma "esfera pública digital" - conceituada a partir de Habermas, Thompson, Bauman e Jenkins - , a internet se tornou um espaço ativo de participação popular, o que pode ter impactos significativos nos resultados das eleições.

\begin{abstract}
The present study is part of a relatively new media universe: the tools of social media - particularly Twitter, Facebook and YouTube, witch are the objects of this research. We analyzed the performance of the candidates for mayor during the 2012 election in Curitiba. The data were collected during the entire election period, between the months of July and October. The presence of the seven candidates in social media was verified, with weekly monitoring of the increment of postings and the growth of followers - or the opposite process, as the case may be. It was also made a comparison between the data achieved in this study and the numbers of research on voting intentions, the Ibope and Datafolha institutes. The main purpose was to prove that, due to the existence of a "digital public sphere" - conceptualized starting from Habermas, Thompson, Jenkins and Bauman - the internet has become an area of active popular participation, which may have significant impacts on election results.
\end{abstract}

Keywords: Social media. Politc. Election.

\section{Introdução}

É difícil precisar o início da imprensa, levando em consideração que a própria definição do termo tem implicações contraditórias dependendo do aspecto teórico analisado. Ressalta-se, entretanto, seu marco inicial na Europa ocidental: a invenção da prensa de tipos móveis por Johannes Gutenberg, por volta de 1440 . No início, a principal instituição que se 
relacionou a esse advento tecnológico foi a Igreja Católica. Com o passar do tempo, a novidade abrangeu outras áreas importantes da sociedade, como é o caso de uma das atividades sociais mais antigas e vitais: o exercício político. Percebeu-se o potencial de influência política desse novo método de divulgação que fazia, por exemplo, o alcance de um discurso se multiplicar.

O desenvolvimento tecnológico fez que, ao longo dos séculos, novas ferramentas midiáticas surgissem. Os equipamentos eletrônicos, como o rádio e a televisão, perpetuaram a conexão entre a comunicação, a política e as eleições. Com a internet, surgiu um novo universo de interação. Por meio dela é possível veicular mensagens das outras mídias de maneira concomitante - o que a torna um veículo transmidiático. Um elemento é o grande diferencial do meio digital: a possibilidade de interação social é ímpar. No meio cibernético, os usuários falam e se expressam de modo rápido e prático. Por meio das chamadas "ferramentas de mídia social", os cidadãos - e os políticos - têm a possibilidade de divulgar informações que podem se tornar notícias e vir a fazer diferença na sociedade. Com o desenvolvimento dessas ferramentas no mundo todo, surgem dúvidas sobre a comunicação no processo eleitoral. Já que o Facebook e o Twitter vêm desempenhando um papel tão importante, como os candidatos estão lidando com eles?

Nesse contexto, insere-se a presente pesquisa, que partiu da análise quantitativa de dados da eleição de 2012 para a prefeitura de Curitiba. A evolução do pleito foi comparada a partir da perspectiva da participação dos candidatos nas ferramentas de mídia social para determinar qual o papel desempenhado por essas nas campanhas. Sugere-se, inclusive, que uma presença mais ativa na internet se reverteria num melhor resultado eleitoral.

\section{A esfera digital}

Quanto mais nova a geração, mais dificuldade ela tem em diferenciar o "computador" da "internet". Os nascidos no ano 2000, por exemplo, cresceram com uma realidade na qual ambos são diretamente associados. A rede já é considerada "o tecido de nossas vidas" (CASTELLS, 2003, p. 7), e ela intervém cada vez mais no cotidiano dos cidadãos, crescendo em escala exponencial continuamente, como comprovado pelos números. Em 1996, 95 bilhões de mensagens eletrônicas foram enviadas nos Estados Unidos - em comparação às 83 bilhões de cartas convencionais. 
O número de computadores conectados em todo o mundo subiu de 1,7 milhão em 1993 para 20 milhões em 1997 (FERRARI, 2003). Em 2011, por exemplo, o Brasil atingiu a marca de 79,9 milhões de pessoas com acesso à internet (AGUIARI, 2012). É importante ressaltar que esse acesso não se dá apenas por meio de computadores fixos, mas também dispositivos móveis - como smartphones e tablets - que alimentam uma mudança comportamental do receptor midiático. Constitui-se, assim, o que é chamado de cultura de internet, na qual se desenham as novas relações entre produção e recepção midiática, tendo a democracia e a opinião pública papéis importantes na mudança da sociedade como um todo.

A internet pôs fim à noção de distância - pelo menos no que tange à informação. A fronteira geográfica dos países vem se mostrando cada vez mais frágil; a humanidade passou de um espaço rígido, sólido e permanente, da modernidade, para um espaço cibernético com elementos

desprovidos de dimensões espaciais, mas inscritos na temporalidade singular de uma difusão instantânea. Doravante, as pessoas não podem ser separadas por obstáculos físicos ou distâncias temporais. Com a interface dos terminais de computadores e monitores de vídeo, as distinções entre aqui e lá não significam mais nada (VIRILIO, 1991, p. 13 apud BAUMAN, 1999, p. 24-25).

Essa flexibilização alterou o modo com que o indivíduo se porta em relação ao mundo: o que estava geograficamente a milhares de quilômetros agora passa a ser acessível com um clique. 0 "mundo virtual" é líquido, flexível e rápido, o que permite ao usuário consumir informações a uma velocidade inédita na história dos meios de comunicação. Isso se dá basicamente pelo fenômeno da convergência de mídias que iniciou com a evolução da internet, e o posterior desenvolvimento de ferramentas tecnológicas portáteis.

Em complemento, deve-se ressaltar a importância que os media tradicionais desempenham nessa "nova" ferramenta. Nela se concentram os desenvolvimentos tecnológicos "do ontem", que, juntos, constroem a internet: "Bem-vindo à cultura da convergência", cumprimenta Jenkins (2008). É esse o lugar onde as velhas e as novas mídias colidem, onde as mídias corporativas e a alternativa se cruzam, onde o poder do produtor midiático e o do consumidor interagem imprevisivelmente.

Por convergência refiro-me ao fluxo de conteúdos através de múltiplos suportes midiáticos, à cooperação entre múltiplos mercados midiáticos e 
ao comportamento migratório dos públicos dos meios de comunicação, que vão a quase qualquer parte em busca das experiências de entretenimento que desejam. Convergência é uma palavra que consegue definir transformações tecnológicas, mercadológicas, culturais e sociais, dependendo de quem está falando e do que imaginam estar falando (JENKINS, 2008, p. 27).

É importante destacar que o autor não trata da convergência midiática como produto exclusivo do desenvolvimento tecnológico. Ela ocorre também "quando as pessoas assumem o controle das mídias" (JENKINS, 2008 , p. 43), o que a torna um processo social. A ela, o autor relaciona dois conceitos importantes. $O$ primeiro é a inteligência coletiva: processo instituído a partir de comunidades constituídas virtualmente que faz que o coletivismo ultrapasse o senso do pensar individual, proporcionando ao consumo de mídia a caracterização de um processo fundamentalmente social. E o segundo é a cultura participativa: o consumidor midiático contemporâneo está cada vez mais distante da condição de receptor passivo. Com o consumo informado da mídia, ele tem maior chance de se emancipar da lógica mercadológica. Em outras palavras, o indivíduo passa a expor suas próprias opiniões a respeito do conteúdo veiculado, chegando até a produzir o seu próprio - como no caso dos "comentaristas do YouTube", pessoas que utilizam o serviço de compartilhamento de vídeos para se expressar.

O caráter ciberdemocrático da internet é o que permite que o retorno da esfera pública ${ }^{1}$ se concretize; lentamente, é verdade, mas o faz, porque a democracia ganha novas dimensões com a rede. Jenkins (2008) ocupa-se essencialmente do entretenimento, mas essa não é a única possibilidade do ciberespaço. Ele vem se mostrando cada vez mais importante em diferentes aspectos da sociedade, como nos movimentos políticos. E um segmento digital que vem se mostrando relevante é o das ferramentas de mídia social.

O termo "mídia social" ainda gera debate - tanto no meio acadêmico quanto na imprensa. Não há uniformidade de tratamento e termos como "rede social" e "site de relacionamento" também são utilizados.

1 Habermas explica a esfera pública burguesa como a esfera dos entes privados reunidos no espaço público. Eles "reivindicam esta esfera pública regulamentada pela autoridade, mas diretamente contra a própria autoridade, a fim de discutir com ela as leis gerais da troca na esfera fundamentalmente privada, mas publicamente relevante, as leis do intercâmbio de mercadorias e do trabalho social" (HABERMAS, 1984, p. 42). 
De modo geral, pode-se dizer que isso acontece pelo fato de o meio ser relativamente novo, o que acaba prejudicando sua exploração e compreensão:

[...] a internet ainda tem o seu vasto potencial informacional e comunicativo subestimado pelos especialistas em comunicação, pelos educadores, pelos políticos e gestores de serviços públicos, pelos produtores culturais e até pelas organizações da sociedade civil. Faltam-lhes experiência e percepção estratégicas mais refinadas para se extrair desse hipermeio todo o retorno comunicacional possível e também para se estabelecer interação verdadeiramente abrangente e democrática com o público, de forma como não ocorreu antes com nenhum outro meio audiovisual massivo (MAGNONI, 2012, p. 49).

Em 2002 começaram a aparecer os primeiros modelos de rede interativa semelhantes aos atuais. $O$ precursor foi o Friendster, que consistia num serviço no qual os usuários construíam um perfil público a partir de seus dados e o associavam a perfis de amigos e conhecidos. O site alcançou uma audiência surpreendente de 3,3 milhões de usuários em um ano. O boca a boca entre técnicos do Vale do Silício e tribos urbanas serviu para popularizá-lo, o que acabou fazendo com que os servidores não aguentassem a demanda dos usuários. Com isso, novos serviços começaram a surgir, como MySpace, Orkut e Facebook, que vêm se mostrando muito mais importantes que originalmente desenhados:

No mundo conturbado do início do século XXI, as redes sociais da internet têm servido para denunciar, para pedir ajuda política e humanitária, para mobilizar para a solidariedade e a resistência civil, para tentar socorrer os perseguidos, para clamar pelos excluídos e apartados. As entidades sindicais utilizam as ferramentas comunicativas da rede para despertar a consciência de classe e mobilizar contra os ajustes ultraliberais, os contingentes de trabalhadores surpreendidos pela devastadora crise econômica dos EUA e da União Europeia (MAGNONI, 2012, p. 49).

O poder dessas ferramentas, que fazem que o indivíduo real tenha espaço no mundo virtual, ainda não é inteiramente compreendido. Casos emblemáticos vêm acontecendo e novos exemplos de mudanças políticas, sociais e econômicas se evidenciam a cada dia. Magnoni (2012, p. 49) explica que a sociedade civil tem, agora, a possibilidade 
da denúncia online, dentro e fora dos países. Tornou-se possível existir comunicação interna e externa em países em situação de guerra e de censura aos meios convencionais de comunicação, por exemplo. Acontecimentos comprovaram isso, como as eleições de 2009 no Irã e a queda do regime de Hosni Mubarak no Egito em 2011. Em ambos os casos, Twitter e Facebook foram ferramentas fundamentais para as manifestações populares e ajudaram na organização de estratégias locais e internacionais de resistência cidadã e política na exigência de liberdade e de condições de autodeterminação para os povos ameaçados.

É importante ressaltar, entretanto, que por mais que essas ferramentas venham se mostrando surpreendentemente benéficas e inovadoras, as regras do mundo "tradicional" ainda se aplicam.

Isto [a participação das redes sociais na luta pelos direitos dos cidadãos] pode parecer abstrato e apartado das questões prementes para os miIhões de pobres que ainda estão distantes das condições mínimas de bem-estar existencial e de direitos cidadãos. No mundo atual aumenta anualmente o número de vitimados pelas guerras e pelos desastres climáticos. Hordas de refugiados sociais e políticos tentam desesperadamente chegar aos lugares mais seguros e promissores e são barrados por barreiras policiais, econômicas e migratórias (MAGNONI, 2012, p. 49).

Em outras palavras, não se pode dizer que com a liberdade de produção informacional existente nas mídias sociais se encontra a panaceia para todos os problemas da sociedade.

\section{O futuro da comunicação}

Com a internet, surgiram dúvidas em relação ao futuro dos meios de comunicação em geral. Os âmbitos acadêmico e mercadológico discutem frequente e exaustivamente o fim do jornal impresso e a mudança de perfil do rádio. $O$ reinado imagético da televisão, tido como intocado, também entra para o rol dos "ameaçados". Por mais que ela tenha sido a responsável por transformar o universo político-eleitoral, o consumo midiático vem mudando numa velocidade espantosa, como apontam levantamentos recentes.

Uma pesquisa produzida pelo Interactive Advertising Bureau (IAB Brasil) e publicada em 2012, entrevistou 2705 pessoas por e-mail, de modo a compreender a audiência online no país, seu envolvimento com 
a internet, os diferentes tipos de tecnologia, além de investigar a importância crescente do meio virtual no cotidiano brasileiro. A pesquisa foi orientada com foco na publicidade na web, mas os resultados obtidos são válidos para diversas áreas.

Os dados apontam que $21 \%$ dos entrevistados usam a internet por mais de vinte horas semanais, enquanto o percentual de pessoas que assistem à televisão por mais de 20 horas semanais é de $13 \%$. É bem verdade que o acesso à rede é mais fácil e possível em mais meios que o acesso à televisão. Utilizando tablets e smartphones, todo usuário é capaz de entrar em contato com o mundo virtual, enquanto o mundo televisivo requer uma aparelhagem mais específica. Em relação à importância dada pelos usuários às mídias existe uma diferença de $32 \%$ entre a TV e a internet, número percebido em todas as faixas etárias questionadas. De 15 a mais de 55 anos, homens ou mulheres, todos responderam que o meio virtual é o mais importante.

Além disso, os resultados desmistificam a noção de que a internet é uma ferramenta elitizada. Pelo menos no Brasil, o uso da rede - em múltiplas tarefas, de acessar redes sociais a ver vídeos - é comum em todas as faixas de renda que participaram da pesquisa. $E$, seguindo a tendência evidenciada na importância dada às mídias, atividades ligadas à internet (no caso, navegar na web e acessar redes sociais) superam o hábito de assistir à televisão em todas as faixas de renda. Esse acesso cada vez mais universal da rede faz que ela participe um número crescente de etapas da vida dos cidadãos, inclusive o exercício da democracia.

\section{Política, mídia e eleições}

As eleições são consultas democráticas por meio das quais o povo tem o direito de votar e escolher seus governantes em um processo essencialmente comunicacional, independentemente da imprensa. "Afinal, trata-se de comunicar ideias e propostas, convencer, argumentar, emocionar; enfim, de mobilizar mentes e corações em uma disputa, normatizada em ambiente público - dado, aliás, fundamental - , do poder político na sociedade" (RUBIM, 2000, p. 96). Na história contemporânea não se pode negar o efeito do poder midiático no processo eleitoral. "Pode-se dizer que se durante o século passado e o primeiro terço do $\mathrm{XX}$ os comícios eram a essência de qualquer campanha eleitoral, agora esse papel central é desempenhado pelos meios e, especialmente, pela televisão" (ALONSO, 1989, p. 136 apud RUBIM, 2000, p. 97). 
Se antes o relacionamento do político ocorria no contato físico com os eleitores, ele passou a ser mediado pela mídia eletrônica. A política se tornou literalmente visível com as imagens televisivas, o que aproximou os políticos da população. Rubim (2000) explica que o jornalismo pré-televisão - de jornais impressos e do rádio - baseava sua cobertura eleitoral nos eventos que se desenvolviam no universo geográfico e da convivência. Eles transmitiam ao público o que havia acontecido in loco, no espaço real, como em comícios, visitas e passeatas. Com a tela da televisão, acontece o mesmo. Vê-se, ao longo da programação dos canais, a rotina dos candidatos, por exemplo.

a mídia eletrônica gerou um tipo de visibilidade que se caracterizava, ao menos por princípio, pelo que poderíamos chamar "simultaneidade desespacializada": pessoas distantes poderiam fazer-se visíveis praticamente no mesmo instante; poderiam ser ouvidas no exato momento em que falavam; vistas no mesmo momento em que agiam, embora não compartilhassem a mesma esfera espacial com os indivíduos para quem se faziam visíveis (THOMPSON, 2008, p. 23).

O autor explica que esse contato proporcionado pela mídia eletrônica criou uma sociedade de "autopromoção" que possibilitou aos indivíduos e líderes políticos se desnudar de aspectos de si ou de suas vidas pessoais diante de públicos distantes. Relaciona-se a essa ideia a reflexão de Lima (2007, p. 88), que trata da cobertura jornalística dos candidatos e não necessariamente dos partidos, o que causaria uma "crescente 'personalização' da política e que estaria sendo representado como uma disputa entre pessoas (políticos) e não entre propostas políticas alternativas (partidos)".

Independentemente de esse maior contato da persona política ser positivo ou negativo, constata-se que a conjugação da sociedade de autopromoção de Thompson e a capacidade de construção de realidades próprias da televisão concedem maior poder de influência da mídia no jogo político. Com isso, as empresas de comunicação, "pelo poder que emana de sua capacidade única de produzir e distribuir capital simbólico e pela ação direta de seus concessionários e/ou proprietários, se transformaram também em atores com interferência direta no processo político" (LIMA, 2007, p. 89-90).

A evolução da tecnologia prosseguiu e, além do meio impresso, radiofônico e televisivo - que continuam veiculando informações e propaganda política -, surgiu a internet, que é capaz de veicular mensagens 
dos outros meios de maneira concomitante. Ainda não se compreende totalmente qual o peso desse veículo no processo político e eleitoral, mas evidências indicam que seu poder é tão grande quanto os outros meios - ou ainda maior.

O relacionamento da televisão com a internet, entretanto, traz particularidades. É possível elencá-las em quatro pontos inter-relacionáveis, com base em Gurevitch, Coleman e Blumler (2009):

a) O poder da imagem

A cultura imagética introduzida pela televisão não apenas se mantém na internet, como é enfatizada, inclusive no âmbito político.

Líderes políticos que não ficam bem na televisão e não entendem sua gramática implícita enfrentam grandes dificuldades. Na nova ecologia midiática, atores políticos estão sob uma pressão muito maior do que a que enfrentaram para construir imagens midiáticas bem desenvolvidas, não apenas na televisão e na imprensa, mas num grande número de espaços. Ao fazer isso, entretanto, eles têm que competir com muitos outros que estão buscando atenção do público, em termos muito mais igualitários que anteriormente (GUREVITCH; COLEMAN; BLUMLER, 2009, p. 175, tradução nossa).

O ator político, que antes precisava se preocupar com a construção de uma imagem atrativa que emitisse mensagens claras e apelativas ao público para ganhar votos, precisa, agora, entender que isso foi expandido. Enquanto na televisão existem horários e limites de tempo específicos para que ele mantenha contato com seus eleitores, na internet isso acontece sem restrições. A imagem midiática do ator político pode ser consumida a qualquer momento e de qualquer modo. A rede serve, portanto, como uma amplificadora da visibilidade criada pela mídia "anterior".

\section{b) O remix informacional}

A informação virtual tem um caráter líquido e facilmente manipulável pelos usuários, que conseguem alterar nomes e dados facilmente. Sendo assim, é importante que a imagem projetada pelo ator político busque 
ser sólida, de modo a tentar fazer com que ela chegue de modo integral ao eleitor. Sobre isso, diz Thompson (THOMPSON, 2008, p. 23-24):

Além disso, dada a natureza da internet, é muito mais difícil controlar o fluxo de conteúdo simbólico dentro dela e, dessa forma, muito mais difícil para aqueles que estão no poder se assegurem de que as imagens disponíveis aos indivíduos são as que eles gostariam de ver circulando. Desde o advento da imprensa, os líderes políticos descobriram ser impossível controlar inteiramente o novo tipo de visibilidade possibilitada pela mídia e deixá-la completamente a seu contento; agora, com o nascimento da internet e de outras tecnologias digitais, isso ficou mais difícil do que nunca.

\section{c) A esfera pública circulatória}

As questões abordadas nos dois primeiros pontos permitem retornar a discussão acerca da esfera pública, categorizada por Habermas (1984) como uma instituição fundamental no advento da sociedade burguesa.

A esfera pública, conforme mediada pela televisão e tecnologias comunicacionais mais novas, assumiu um lado anti-institucional, focando mais numa presença pública informal, comunitária e interligada. Em muitos aspectos, as redes midiáticas digitais são mais sensíveis a essa esfera pública circulatória que a televisão, com sua distância centralizada das bases fundamentais, consegue ser (GUREVITCH; COLEMAN; BLUMLER, 2009, p. 175, tradução nossa).

A esfera pública formalizada e que necessitava de um espaço físico agora recebe seu final blow. Com a possibilidade de discussões políticas via web, ela volta a se reconstituir por meio da informalidade e de uma proximidade inédita do usuário.

\section{d) Comentaristas plurais}

O funcionamento padrão das emissoras de televisão previa comentaristas políticos determinados, cujas opiniões eram imbuídas imediatamente de credibilidade e confiança - talvez proporcionadas pelo 
"formalismo jornalístico". Os avanços tecnológicos fizeram com que equipamentos audiovisuais, ou até mesmo a construção de um blog ou website, tornassem-se tão fáceis quanto ligar a televisão e assistir a comentários de outras pessoas. Com isso, é possível que o próprio usuário produza seus comentários e os divulgue na rede mundial de computadores.

\section{Metodologia e resultados da pesquisa}

A partir da oficialização das candidaturas à prefeitura de Curitiba teve início o acompanhamento das contas do Twitter, Facebook e YouTube de cada candidato: Alzimara Bacellar (PPL), Avanilson Araújo (PSTU), Bruno Meirinho (PSOL), Gustavo Fruet (PDT), Luciano Ducci (PSB), Rafael Greca (PMDB) e Ratinho Junior (PSC). A coleta de dados iniciou no dia 10 de julho e terminou no dia 9 de outubro, um dia depois da divulgação dos resultados do primeiro turno.

Ficou determinado que, à meia noite das terças-feiras, seriam acessadas as contas de todos os candidatos para a realização da medição. Esse horário foi escolhido por ser um momento em que nenhum deles, pelo menos em tese, estaria conectado, o que garantiu chances iguais a todos os analisados. Foram contabilizados:

- no Twitter, número de tweets, número de pessoas seguidas pelo perfil do candidato, número de seguidores;

- no Facebook, número de likes conquistados pelas páginas oficiais;

- no YouTube, número de vídeos enviados; número de inscritos nos canais dos candidatos; número de visualizações dos vídeos.

Com essas informações, foi construído um quadro quantitativo que possibilitou uma análise estatística dos dados para se comparar o crescimento de seguidores/usuários/visualizações com os dados das pesquisas eleitorais e com o resultado das urnas.

Já que se objetiva estabelecer uma relação entre os resultados eleitorais e o público das ferramentas de mídia social, apresentam-se os índices de intenção de voto obtidos pelos candidatos de acordo com as quatro últimas pesquisas realizadas pelo IBOPE antes do primeiro turno. Na rodada de 24 de agosto, Ratinho Junior liderava com $27 \%$ das intenções de voto, seguido com Luciano Ducci com 23\% e Gustavo Fruet com $21 \%$. No dia 14 de setembro, havia uma ligeira vantagem de Ducci, 
que apareceu com 31\%, contra 30\% de Ratinho e 16\% de Fruet. Em 2 de outubro, Ratinho Junior chegou a 35\%; Ducci ficou com $28 \%$ e Fruet manteve 16\%. Na última rodada, divulgada em 6 de outubro, Ratinho permaneceu com 35\%, Ducci desceu para $26 \%$ e Fruet chegou a $19 \%$. Entre os demais candidatos, Rafael Greca pontuou com índices inferiores a $10 \%$ em todas as pesquisas; os outros ficaram com traços.

\section{Twitter}

As coletas feitas para o trabalho trazem resultados como a média total de seguidores (cálculo obtido pelo somatório de seguidores dividido pelas 14 semanas de verificação), número de novos seguidores ao longo da campanha e média do número de postagens na rede de microblogging $^{2}$. A Tabela 1 mostra a média de seguidores e os novos seguidores obtidos pelos candidatos.

Tabela 1 - Candidatos com seguidores no Twitter e sua evolução

\begin{tabular}{llcc}
\hline Nome & Twitter & Média & Novos seguidores \\
\hline Ratinho Junior & ratinho_jr & 10.736 & 1.851 \\
Gustavo Fruet & gustavofruet & 10.452 & 1.071 \\
Luciano Ducci & LucianoDucci & 5.335 & 487 \\
Rafael Greca & rafaelgreca15 & 5.215 & 827 \\
Bruno Meirinho & brunomeirinho & 416 & 132 \\
Avanilson Araújo & avanilsonPSTU & 390 & 39 \\
\hline
\end{tabular}

Fonte: Dados da pesquisa.

O candidato Ratinho Junior ficou à frente dos demais na contagem final dos resultados, tanto em número médio de seguidores como na obtenção de novos ao longo da campanha. Deve-se ressaltar, entretanto, que nas quatro primeiras semanas de análise (nos dias 10, 17, 24 e 31 de

2 A candidata Alzimara Bacellar não possuía conta no Twitter e por isso não figura nos resultados dessa ferramenta de mídia social. 
julho) era Gustavo Fruet quem liderava no número médio de seguidores. Ratinho Junior só ultrapassou o primeiro colocado na semana do dia 7 de agosto. Tem-se, de qualquer modo, o "campeão" do Twitter em termos de maior popularidade refletida pelo maior número de seguidores. Ratinho Junior conseguiu 1.851 novos seguidores ao longo da campanha, superando o segundo colocado em 780 seguidores.

A Tabela 2 apresenta a relação entre o número de postagens e o número de seguidores, para conferir se a quantidade de tweets teve algum reflexo no aumento de seguidores, sendo determinado, portanto, quem mais postou no Twitter.

Tabela 2 - Quantidade de tweets (por posição)

\begin{tabular}{llcc}
\hline Nome & Twitter & $\begin{array}{c}\text { Tweets ao longo da } \\
\text { campanha }\end{array}$ & Média semanal \\
\hline Rafael Greca & rafaelgreca15 & 3.610 & 257 \\
Gustavo Fruet & Gustavofruet & 638 & 45 \\
Ratinho Junior & ratinho_jr & 546 & 39 \\
Luciano Ducci & LucianoDucci & 454 & 32 \\
Bruno Meirinho & brunomeirinho & 154 & 11 \\
Avanilson Araújo & avanilsonPSTU & 11 & 0,7 \\
\hline
\end{tabular}

Fonte: Dados da pesquisa.

Para chegar a esses números, foram considerados apenas os tweets publicados entre os dias inicial e final de campanha. É importante fazer um recorte para que não sejam utilizados valores errôneos. Rafael Greca, por exemplo, terminou a participação na pesquisa com 18.949 tweets, mas entrou nela com 15.339.

O candidato mais prolixo no Twitter foi justamente ele, totalizando 3.610 postagens entre os dias 10 de julho e 9 de outubro - número cinco vezes maior que o de Fruet, segundo colocado, e mais que 328 vezes maior que Avanilson Araújo, que postou meros 11 tweets. Em termos semanais, portanto, Greca atingiu a média de 257 postagens. Ao comparar as duas tabelas, percebe-se que falar muito na rede não resultou em um maior número de seguidores: Ratinho Junior postou 546 vezes e conseguiu 1.851 seguidores, enquanto Greca postou 3.610 e obteve 827. 


\section{Facebook}

A rede com mais de 50 milhões de usuários no Brasil (BRASIL..., 2012) apresentou números bem maiores que o da rede de microblogging. Foram coletadas informações exclusivamente das páginas dos candidatos, as chamadas fanpages, as quais os usuários têm a possibilidade de "curtir" ou, nos termos do Facebook, dar "like". A Tabela 3 mostra a média obtida ao dividir o somatório de curtidas pelas 14 semanas de verificação e a evolução do número de likes.

Tabela 3 - Likes médios e sua evolução

\begin{tabular}{llcc}
\hline Nome & Página & Médlia & Novos likes \\
\hline Ratinho Junior & Ratinhojunior & 22519 & 4361 \\
Gustavo Fruet & Gustavofruet & 14825 & 2011 \\
Rafael Greca & rafaelgreca15 & 6465 & 1605 \\
Luciano Ducci & LucianoDucci & 6047 & 1167 \\
Bruno Meirinho & BrunoMeirinh050 & $356^{*}$ & 599 \\
Alzimara Bacellar & Alzimara.Bacellar2 & $122^{* *}$ & 163 \\
Avanilson Araújo & PrefeitoAvanilsonArauj016 & $25^{*}$ & 31 \\
\hline
\end{tabular}

Fonte: Dados da pesquisa.

Nota: * Os candidatos só criaram uma página no Facebook na quinta semana de verificação. ** A candidata só criou uma página no Facebook na quarta semana de verificação.

Logo se vê que os dois primeiros colocados são os mesmos do Twitter. $\mathrm{Na}$ terceira e quarta posições estão Rafael Greca e Luciano Ducci, que ocupam lugares opostos nesta ferramenta de mídia social, pelo menos em relação à média de seguidores comparada com a de likes. Dentre os candidatos "pequenos" - isto é, que criaram páginas depois da definição das candidaturas, Bruno Meirinho se destaca. Mesmo tendo mantido uma página por 10 semanas, tempo igual ao de Avanilson Araújo e uma semana a menos que Alzimara Bacellar, ele atingiu a média de 356 likes. 


\section{YouTube}

Foram considerados, na Tabela 4, apenas canais próprios do candidato, o que excluiu Avanilson Araújo da análise, já que seus vídeos eram veiculados no canal do partido. Na seção quantitativa, a média foi obtida dividindo o número de vídeos pelo número de visualizações até o dia da verificação. Não coube verificar quem teve "o maior desenvolvimento", já que o número de vídeos de cada um variou - enquanto Alzimara Bacellar chegou ao máximo de 6 vídeos, por exemplo, Luciano Ducci ficou na margem de 360 . Serão feitas, portanto, considerações individuais.

Tabela 4 - Visualizações/Número de vídeos

\begin{tabular}{|c|c|c|c|c|c|c|}
\hline \multirow[b]{2}{*}{ Datas } & \multicolumn{6}{|c|}{ Canal } \\
\hline & $\begin{array}{c}\text { Ratinhoju- } \\
\text { niorTV }\end{array}$ & $\begin{array}{c}\text { Gustavo- } \\
\text { Fruet }\end{array}$ & $\begin{array}{l}\text { DrLuciano- } \\
\text { Ducci }\end{array}$ & $\begin{array}{l}\text { rafael- } \\
\text { greca15 }\end{array}$ & Alzimara54 & $\begin{array}{c}\text { TVBru- } \\
\text { no50 }\end{array}$ \\
\hline 10/jul. & 83 & 134 & 126 & - & - & - \\
\hline 17/jul. & 84 & 137 & 128 & - & - & - \\
\hline 24/jul. & 85 & 147 & 131 & - & - & - \\
\hline 31/jul. & 86 & 153 & 132 & - & - & - \\
\hline 07/ago. & 87 & 163 & 130 & 98 & - & - \\
\hline 14/ago. & 88 & 160 & 133 & 91 & - & - \\
\hline 21/ago. & 88 & 167 & 146 & 95 & - & - \\
\hline 28/ago. & 91 & 204 & 144 & 221 & 64 & 177 \\
\hline 04/set. & 93 & 236 & 153 & 356 & 90 & 229 \\
\hline 11/set. & 1110 & 247 & 155 & 346 & 68 & 267 \\
\hline 18/set. & 1111 & 284 & 166 & 405 & 99 & 279 \\
\hline 25/set. & 1108 & 290 & 166 & 434 & 124 & 317 \\
\hline 02/out. & 1085 & 298 & 175 & 442 & 128 & 339 \\
\hline 09/out. & 1113 & 355 & 200 & 461 & 155 & 365 \\
\hline
\end{tabular}

Fonte: Dados da pesquisa. 
Ratinho Junior manteve uma taxa constante de crescimento nas visualizações até 4 de setembro, quando tinha 323 vídeos (número que se manteve por oito semanas consecutivas) produzidos pela Rede Massa, afiliada do SBT em Curitiba, canal de televisão de seu pai - e tratavam de assuntos da Câmara Federal, onde o candidato cumpria mandato parlamentar antes de se candidatar a prefeito. Em setembro, todos desapareceram, sendo substituídos pelos de campanha. Deduz-se que a variação entre os dias 4 e 11 de setembro se dê por erro do sistema do YouTube, que manteve o número de visualizações considerando esses vídeos excluídos e não computou apenas os ainda presentes no canal.

Percebeu-se, desde o início da campanha de Gustavo Fruet o uso do canal com foco eleitoral. As visualizações médias seguiram um crescimento constante, e o número de vídeos enviados não teve uma grande variação, ficando na média de 65 . Ao final da verificação, ele havia enviado 102 vídeos.

O primeiro vídeo hospedado no canal de Luciano Ducci data de 2010 e muitos deles são de ações do candidato como prefeito. $O$ número de envios é grande, ficando acima dos 300 . Entre as semanas dos dias $14 / 08$ e 21/08, houve um processo inverso: o número de vídeos caiu de 363 para 338. Na semana do dia 28, o número de envios subiu para 342 e continuou subindo até o dia 2 de outubro, atingindo a marca de 382 vídeos. Ao final, entretanto, o canal indicava a presença de apenas 355 envios - tendo sido excluídos 27.

No caso de Rafael Greca, houve um hiato nas análises do canal do candidato porque ele era detentor de dois, o "rafaelgrecaoficial", que estava sendo analisado anteriormente, e o "rafaelgreca15", que foi o canal oficial da campanha. Esse candidato teve um salto no número médio de visualizações a partir da semana do dia 28 de agosto, em grande parte por causa de um único vídeo que chamou bastante a atenção dos eleitores. Com 24.683 visualizações (até o dia 24 de setembro), "Asfalto vira pó" foi compartilhado intensamente nas ferramentas de mídia social, alavancando o canal de Rafael Greca, que manteve os maiores índices proporcionais quando comparados aos outros candidatos (a não ser por Ratinho Junior, mas seus números são desconsiderados pela inconsistência das médias).

Alzimara Bacellar e Bruno Meirinho não possuíam contas no YouTube até a semana do dia 28 de agosto. Bruno Meirinho passou a usar a ferramenta com frequência, ficando na média de 36 vídeos enviados. Alzimara, em contrapartida, fica na média de quatro envios. 


\section{Resultados eleitorais}

Com a apuração das urnas eletrônicas no dia 7 de outubro de 2012, o primeiro turno das eleições em Curitiba teve o seguinte resultado: Ratinho Junior, 34,09\% (332.408 votos); Gustavo Fruet, $27,22 \%$ (265.451 votos); Luciano Ducci, 26,77\% (261.049); Rafael Greca, 10,45\% (101.866); Bruno Meirinho, 0,91\% (8.878 votos); Alzimara, 0,46\% (4.518) e Avanilson, $0,10 \%$ (1.012 votos). Com isso, tem-se que as pesquisas de intenção de voto não conseguiram prever um resultado das eleições na cidade. As ferramentas de mídia social, em contrapartida, ficaram mais próximas da realidade: os dois candidatos mais populares no Twitter e no Facebook foram também os mais populares nas urnas e passaram para o segundo turno.

$\mathrm{Na}$ fase decisiva do pleito, as sondagens de intenção de voto do Instituto Datafolha mostraram uma mudança na liderança: no dia 27 de outubro, Fruet aparece com $54 \%$ das intenções de voto e Ratinho Junior com $36 \%$. Nessa etapa, a pesquisa continuou acompanhando os candidatos na mídia social. Gustavo Fruet passou de 15.317 likes em 02 de outubro para 20.969 likes no dia 9; ao passo que Ratinho Junior, sempre líder isolado nesse quesito, passou de 24.776 para 26.440 likes no mesmo período. Esse quadro se manteve ao longo das verificações, que foram feitas com maior frequência, já que os números se alteravam rapidamente. Na semana seguinte, no dia 16 de outubro - antes mesmo da divulgação da primeira pesquisa de intenção de voto -, Gustavo Fruet superou o adversário. Na data do segundo turno, 28 de outubro, o líder computava 32.703 likes e Ratinho Junior tinha 29.681. Dessa vez, os dois índices (institutos de pesquisa e mídia social) foram capazes de mostrar o resultado das urnas: Gustavo Fruet foi eleito prefeito com $60,65 \%$ dos votos, contra 39,35\% de Ratinho Junior.

\section{Considerações finais}

Sobre a relação do desempenho eleitoral e o uso de ferramentas de mídia social, percebeu-se que essas se provaram indicadoras da provável vitória dos candidatos. Por exemplo, enquanto as pesquisas eleitorais do primeiro turno apontavam para um quadro de segundo turno, a popularidade conquistada pelos candidatos nas redes sociais indicava outro ranking, que se confirmou nas urnas. 
É importante, entretanto, relativizar esse resultado. Afinal, os universos dos dados utilizados são diferentes: na última pesquisa de intenção de voto realizada pelo Ibope, no dia 6 de outubro, foram entrevistados 1.001 eleitores; no dia 2 de outubro, nas ferramentas de mídia social, Ratinho Junior tinha 11.452 seguidores e 24.776 curtidas, enquanto Gustavo Fruet tinha 10.628 pessoas o seguindo e 15.317 likes em sua página oficial; no resultado final das urnas do primeiro turno, o primeiro colocado conseguiu 332.408 votos e o segundo 265.451. São números e pessoas diferentes já que, por exemplo, o entrevistado pelo instituto de pesquisa não necessariamente segue um candidato na internet.

As redes sociais têm um funcionamento essencialmente diferente do voto ou da pesquisa: enquanto esses exigem uma escolha única, elas abrem margem para que se interaja com todos. Jornalistas interessados em saber como os candidatos se comportam na internet podem, naturalmente, "seguir" ou "curtir" todos que concorrem ao pleito e isso não significa, obviamente, que votarão em todos eles. Mesmo que o ato de seguir ou curtir não implique no voto, ele acaba, direta ou indiretamente, aumentando a visibilidade dos candidatos. Não é possível estabelecer uma relação causal em que o "mais popular na rede" é o vitorioso nas urnas, mas esses números não caminham em direções opostas.

A galáxia das campanhas eleitorais é só mais uma do universo social que é alvo dos clamores populares transmitidos pela rede, que acaba, assim, funcionando como uma ferramenta da democracia. Como enunciado por Gurevitch, Coleman e Blumler (2009, p. 175), "na nova ecologia midiática, atores políticos estão sob maior pressão que nunca estiveram para construir imagens midiáticas bem desenvolvidas, não apenas na televisão e na imprensa, mas num grande número de espaços". Os políticos devem buscar estar mais próximos da sociedade, seja por vontade própria ou por necessidades eleitorais. Caso não o façam, serão pressionados a fazê-lo. A transparência, quando não conseguida naturalmente, é exigida pelo público, e as ferramentas de mídia social atuam justamente aí, conferindo maior visibilidade àquilo que "o povo quer" e construindo, assim, uma realidade mais participativa.

\section{Referências}

AGUIARI, V. Brasil fecha 2011 com 79,9 mi de internautas. Exame.com, 10 abr. 2012. Disponível em: <http://exame.abril.com.br/tecnologia/noticias/brasil-fecha-2011-com-79-9-mi-de-internautas>. Acesso em: 20 abr. 2012. 
BAUMAN, Z. Globalização: as conseqüências humanas. Tradução de Marcus Penchel. Rio de Janeiro: Jorge Zahar, 1999.

CASTELLS, M. A galáxia da internet: reflexões sobre a internet, os negócios e a sociedade. Tradução de Maria Luiza X. de A. Borges. Rio de Janeiro: Jorge Zahar, 2003.

FERRARI, P. Jornalismo digital. São Paulo: Contexto, 2003.

BRASIL ultrapassa 50 milhões de usuários no Facebook, diz pesquisa. G1, São Paulo, 29 jun. 2012. Disponível em: <http://g1.globo.com/tecnologia/noticia/2012/06/ brasil-ultrapassa-50-milhoes-de-usuarios-no-facebook-diz-pesquisa.html>. Acesso em: 3 jul. 2012.

GUREVITCH, M.; COLEMAN, S.; BLUMLER, J.G. Political communication - old and new media relationships. The Annals of American Academy of Political and Social Science, v. 625, p. 164-181, Sept. 2009.

INTERACTIVE ADVERTISING BUREAU - IAB Brasil. Pesquisa de audiência. Disponível em: <http://iabbrasil.net/portal/institucional-iab/indicadores-mercado/>. Acesso em: 20 jul. 2012.

HABERMAS, J. Mudança estrutural da esfera pública: investigações quanto a uma categoria da sociedade burguesa. Tradução de Flávio R. Kothe. Rio de Janeiro: Tempo Brasileiro, 1984.

JENKINS, H. Cultura da convergência. Tradução de Susana Alexandria. São Paulo: Aleph, 2008.

LIMA, V. A. de. Comunicação e política. In: DUARTE, J. (Org.). Comunicação pública: Estado, mercado. sociedade e interesse público. São Paulo: Atlas, 2007.

MAGNONI, A. F. A comunicação e a opinião pública na era das redes sociais. In: SANTOS, C. M. R. G. dos. (Org.). Opinião pública: empowerment e interfaces. Bauru: Universidade Estadual Paulista, Faculdade de Arquitetura, Artes e Comunicação, 2012.

RUBIM, A. A. C. Comunicação e política. São Paulo: Hacker Editores, 2000.

THOMPSON, J. B. A nova visibilidade. Matrizes, v. 1, n. 2, 2007.

Recebido: $16 / 02 / 2013$

Received: 02/16/2013

Aprovado: 27/05/2013

Approved: 05/27/2013 